\title{
Mechanical behaviour of high metakaolin lightweight aggregate concrete
}

\author{
A. Al-Sibahy \& R. Edwards \\ Department of Mechanical, Aerospace and Civil Engineering, \\ University of Manchester, UK
}

\begin{abstract}
The work described in this paper forms part of a much larger investigation of the behaviour of a new developed type of lightweight aggregate concrete which would be suitable for use as load bearing concrete masonry units. The experimental work investigated the effect of high metakaolin (MK) content on the mechanical behaviour of newly modified lightweight aggregate concrete. $15 \%$ metakaolin and waste glass were used as a partial replacement for both ordinary Portland cement and natural sand. A medium grade expanded clay type Techni Clay was used as a coarse aggregate in the concrete mixes. Equal amounts of waste glass with particles sizes of 0.5-1 and 1-2 mm were used throughout this study. Unit weight, compressive and splitting tensile strengths were measured at various ages in accordance with the relevant British/EN standards. Fresh concrete properties were observed to justify the workability aspect. An assessment was carried out to indentify the pozzolanic activity of metakaolin material. The tests results were compared with the obtained results of controlled and lower metakaolin contents concretes which were previously studied. The tests results showed that metakaolin material had an explicit role in improving the strength and unit weight of modified lightweight concrete mixes. Compressive and splitting tensile strengths increase with an increase in the metakaolin content, while a counteractive behaviour was recorded for the unit weight aspect. The metakaolin material showed higher pozzolanic activity which was overcame there duction of compressive strength due to the negative effect of glass aggregate. However, the workability of concrete mixes degraded at higher metakaolin inclusion.
\end{abstract}

Keywords: lightweight aggregate concrete, metakaolin, waste glass, mechanical behaviour. 


\section{Introduction}

In recent years, much research has been undertaken with the aim of improving the mechanical properties of lightweight concrete. Improvements to the strength and unit weight are the major keys to evolution of the lightweight concrete behaviour. The strength characteristic represents the load bearing capacity of concrete to support the applied load. Unit weight is an indicator for its lightness and capability to afford thermal insulation when used within the internal and external building elements. This orientation also associated with environmental aspects in the construction processes, and the idea of environmental friendly solution showed up during the last few decades.

Due to huge amounts of waste glass produced in UK, crushed or ground glass aggregate is one of most effective environmental treatments to mitigate these wastes. The features of glass aggregates are granular particle shape, smooth surface texture and very low tendency to absorb the mixing water. These characteristics produce dry consistency and lower strength concrete mix. There is a slight increase in alkali-silica reaction ASR of glass aggregate concrete compared with normal aggregate concrete. However, this reaction can be reduced by using mineral by product materials.

In the concrete mixes, the crushed and ground glass aggregates are usually used as a partial replacement to the coarse or fine aggregate and Portland cement respectively [1].

Metakaolin is a versatile mineral by product material which can be used to improve the strength and durability of concrete mixes. It has a higher ratio of pozzolan and it is used as a construction material has sharply increased with consumption grows every year on a global basis. The production of metakaolin is by calcinations of kaolinitic clay at $\left(650^{\circ} \mathrm{C}-800^{\circ} \mathrm{C}\right)$. It has surface area larger than Portland cement reach to about15 times with a specific gravity about $2.4 \mathrm{~g} / \mathrm{cm}^{3}$. It is usually used as a partial replacement for Portland cement. Since the use of metakaolin material reduces the emissions of $\mathrm{CO}_{2}$ during cement manufacture, it was considered in the industry for the production of precast concrete [2-4].

Expanded clay is an artificial lightweight aggregate which is considered as an essential approach to reduce the demand on the natural aggregate. Concrete mixes producing by this approach providing several advantages such as (1) Reduction of dead load of building that will reduce the dimensions of structural members giving a reduction in the quantity of reinforcement. (2) Lighter and smaller pre-cast elements which lead to less expansive casting, handling and transportation operations. (3) Providing large space due to reductions in the sizes of columns, beams and slabs dimensions. (4) High thermal insulation and increased fire resistance [5].

A newly modified lightweight concrete containing combination of expanded clay, waste glass and metakaolin materials was investigated, and, herein, the mechanical behaviour of highly metakaolin ratio is concerned. 


\section{Experimental program}

The experimental program of this research aims to investigate the mechanical behaviour of high metakaolin lightweight concrete which would be suitable for use as a load bearing concrete walls.

A medium grade expanded clay type Techni Clay was used as coarse aggregate in the concrete mixes. This type of expanded clay was produced by the Plasmor Concrete Product Company. It has a typical moisture content and particle density of $20 \% \mathrm{ww}$ and $550 \mathrm{~kg} / \mathrm{m}^{3}$ respectively. Figure 1 shows the grading of expanded clay.

Natural sand for building proposes was used as a fine aggregate to produce concrete mixes. Grading of the used sand is shown in Figure 1.

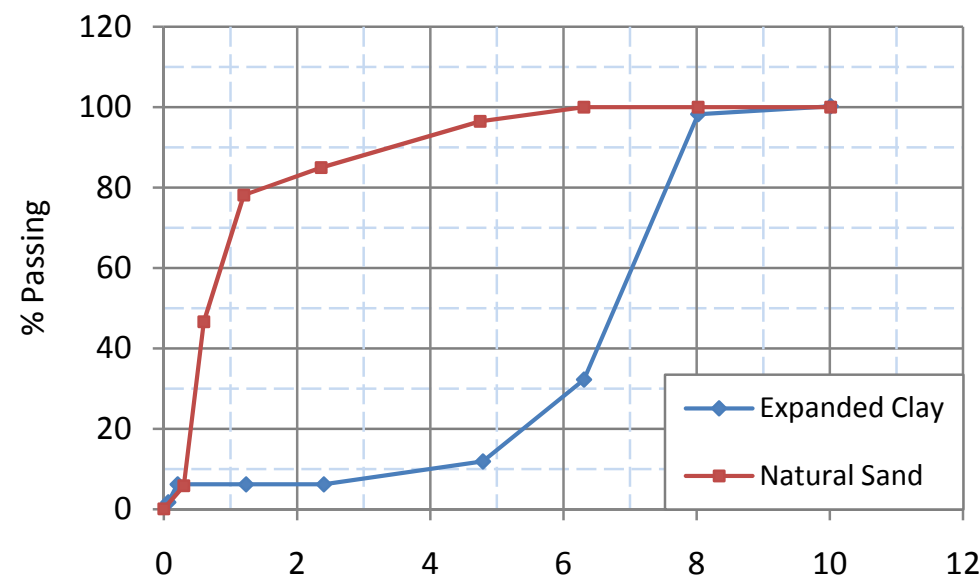

Sieve size $\mathrm{mm}$

Figure 1: Grading of expanded clay and natural sand.

Waste glass with particles size of 0.5-1 and 1-2 mm was used as a partial replacement to natural sand with ratio of $15 \%$ by volume. The waste glass was provided by the Specialist Aggregate Ltd Company with a specific gravity of 2.52 .

Metakaolin material was used as a partial replacement to the ordinary Portland cement with ratio of $15 \%$ by weight.

The mix proportions were 1: $0.76: 1.5$ by volume which was equivalent to 1 : 1.27: 0.63 by weight with $50 \mathrm{~mm}$ slump. Cement content and $\mathrm{W} / \mathrm{C}$ ratio of controlled concrete $\left(0 \%\right.$ glass $+0 \%$ metakaolin) were $392 \mathrm{~kg} / \mathrm{m}^{3}$ and 0.45 respectively. Figure 2 shows the materials which were used in producing the lightweight concrete mixes.

The mixing operation was carried out according to BS EN12390-2 [6] using $0.1 \mathrm{~m}^{3}$ vertical portable mixer. The fresh concrete was casted in moulds by 
means of three layers. Each layer was completely compacted using a vibrating table until there was no further appearance of large air bubbles on the surface of the concrete. The excessive concrete above the upper edge was removed to achieve relatively smooth surface by using steel trowel.

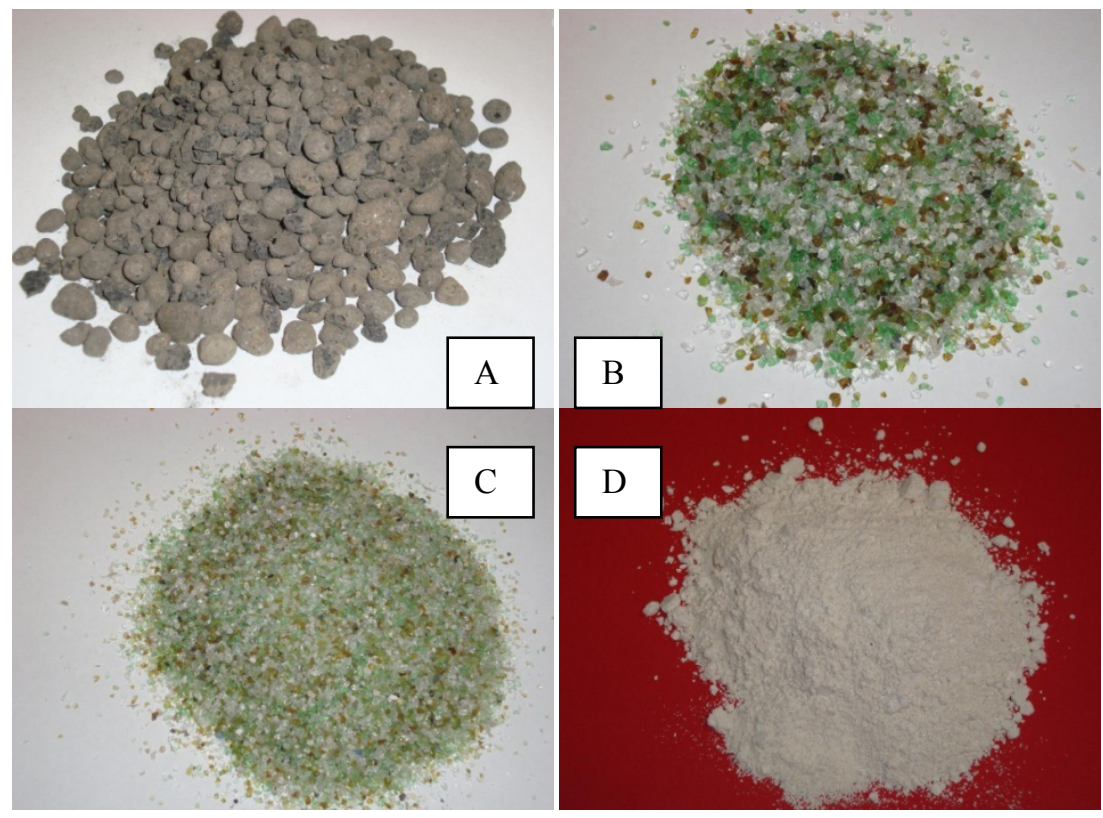

Figure 2: The used materials in the experimental program: A- Expanded clay, B- Waste glass 1-2 mm, C-Waste glass $0.5-1 \mathrm{~mm}$ and D- metakaolin material.

After casting, the samples were kept out in the laboratory condition and coated by nylon sheet to ensure a humid air around the specimens. After 24 hours, the samples were demoulded, marked and immersed in a basin of water at a temperature $20 \pm 2^{\circ} \mathrm{C}$ until the date of test.

Before performing the experimental tests, the apparent moisture was removed from the specimens, and the surfaces were cleaned from any loose grit or any other materials that could be in contact with the loading plate.

The mechanical behaviour tests included unit weight, compressive and splitting tensile strengths. All these tests were conducted according to the relevant British /EN standards [7-11].

An average value of three specimens was adopted for each test result. Short and long term behaviours were investigated. The tests results were compared with the obtained results of controlled and lower metakaolin contents concrete samples which were previously studied. 


\section{Experimental results and discussion}

\subsection{Workability of concrete mixes}

The approach of workability test was maintaining a constant amount of mixing water (water/cementitious ratio) for all metakaolin replacements. The worst workability was recorded for a mix containing $15 \%$ metakaolin. It required more effort using vibration process to cast. This may be related to the higher specific surface area of metakaolin particles compared to ordinary Portland cement. This caused a higher tendency to absorb the mixing water, sequentially accelerates the cement hydration and increases the micro-hardness of the paste-aggregate interfacial zones [3]. The lower metakaolin contents seem to be adequate in term of workability.

\subsection{Unit weight}

The unit weight behaviour of controlled and modified concrete mixes at different test ages is shown in Figure 3. Modified concrete mixes showed slightly lower density than the controlled mix. This is expected as the specific gravity of waste glass at 2.52 is less than that for natural sand at 2.65. Since the glass replacement was by volume of natural sand, the resulting unit weight of concrete will be reduced. Among the used metakaolin replacements, the ratio of $10 \%$ showed the higher decreasing in value of unit weight, while $15 \%$ metakaolin replacement produced the heaviness modified concrete mix. These results confirm with the previous studies [4].

In general, all lightweight aggregate concrete mixes exhibited a continuous decrease in density with increasing age of test except at 28 days for the modified

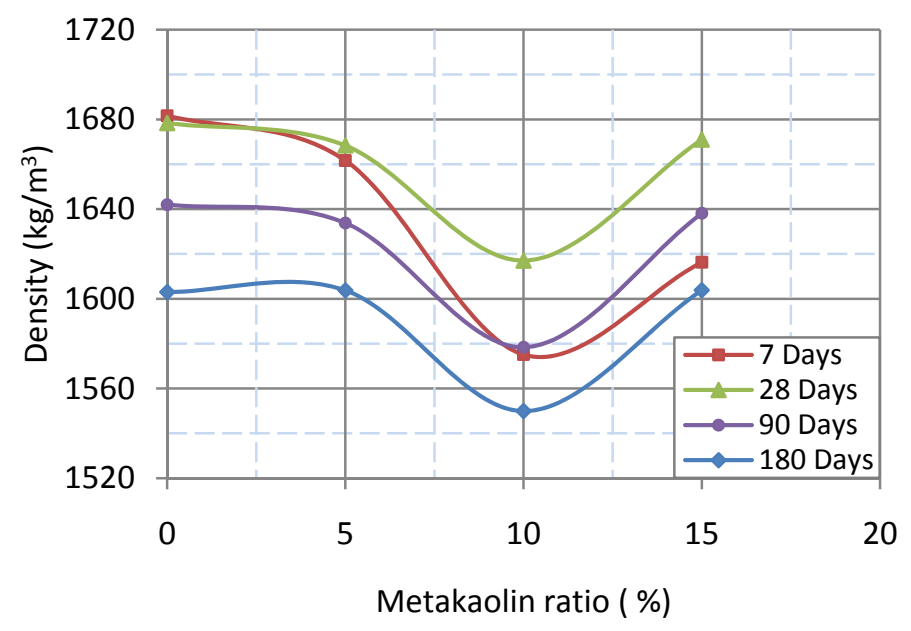

Figure 3: Effect of metakaolin ratio on the density of lightweight concretes. 
concrete mixes (Figure 4). This behaviour may be attributed to two phenomena: the first is the consumption of the mix water by hydration processes, the second is reduction of free water from the gel pores by evaporation. Increasing density of modified concrete mixes at age of 28 days compared with that at 7 days could be explained by the higher hardness of these mixes due to pozzolanic reaction of metakaolin material associated with their capability to hold the mixing water.

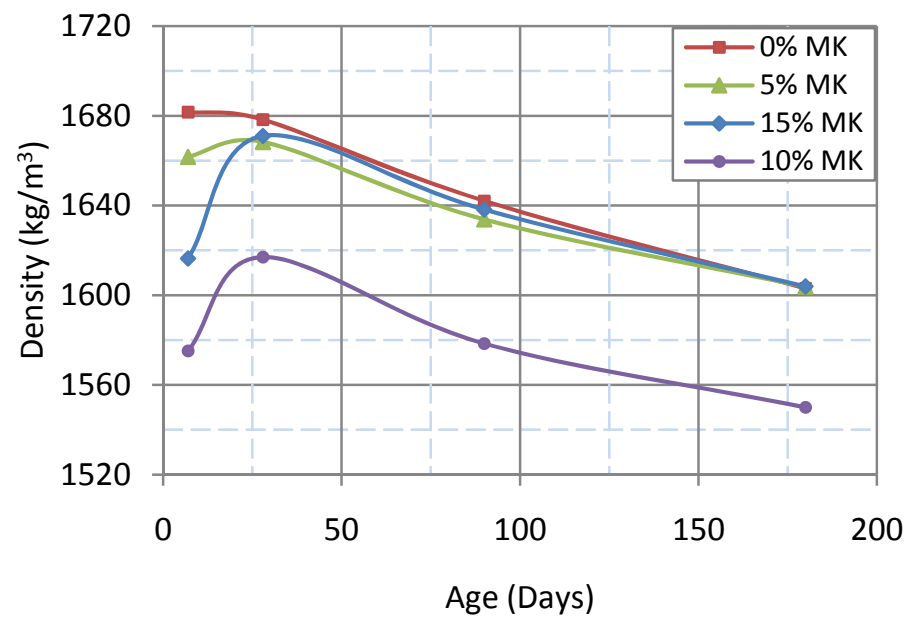

Figure 4: Density-age relationship of different metakaolin ratios.

\subsection{Compressive strength}

The tests results of compressive strength are presented in Figure 5. This figure indicates that the modified concrete mixes possess higher values of compressive strength than the controlled mix. This performance could be related to the filler and pozzolanic reaction of metakaolin material which improves growth of compressive strength, in addition to the acceleration of Portland cement hydration $[3,4]$. Due to the high silica content of the pozzolanic material, it has capability to react with the calcium hydroxide which liberated from hydration process to produce gel of calcium silicate hydrate $(\mathrm{CSH})$. The $\mathrm{CSH}$ component is the essential responsible of the concrete strength [12-14].

$$
\mathrm{SiO}_{2}+\mathrm{Ca}(\mathrm{OH})_{2} \rightarrow \mathrm{CSH}
$$

For all concrete mixes, the compressive strength increase with the increasing of time as shown in Figure 6. Percentage increases in compressive strength for concrete mixes containing 5\%,10\% and $15 \%$ metakaolin material at age of 90 days compared with the controlled concrete at the same age were $4.45 \%, 10.71 \%$ and $21.6 \%$ respectively. 


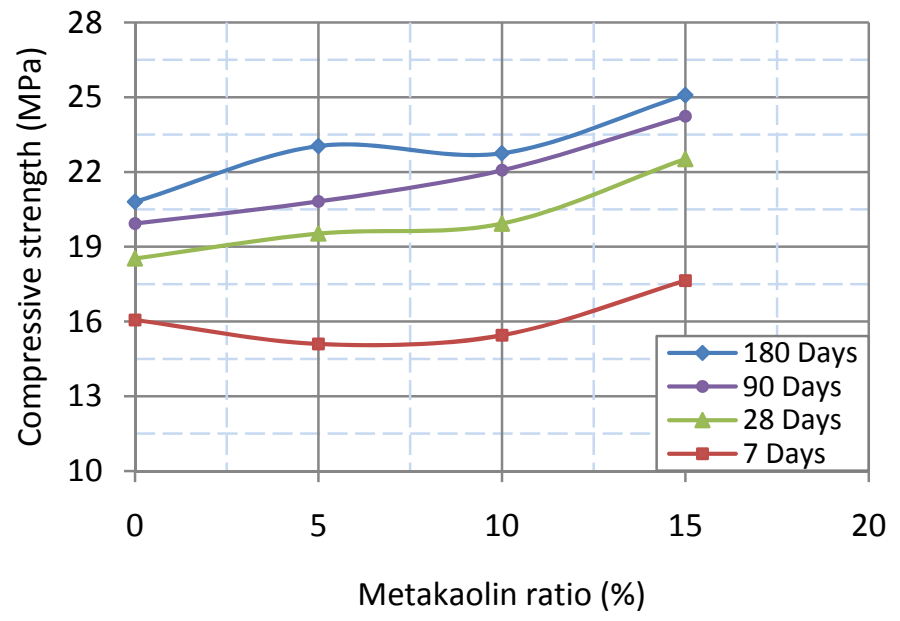

Figure 5: Effect of metakaolin ratio on the compressive strength of lightweight concretes.

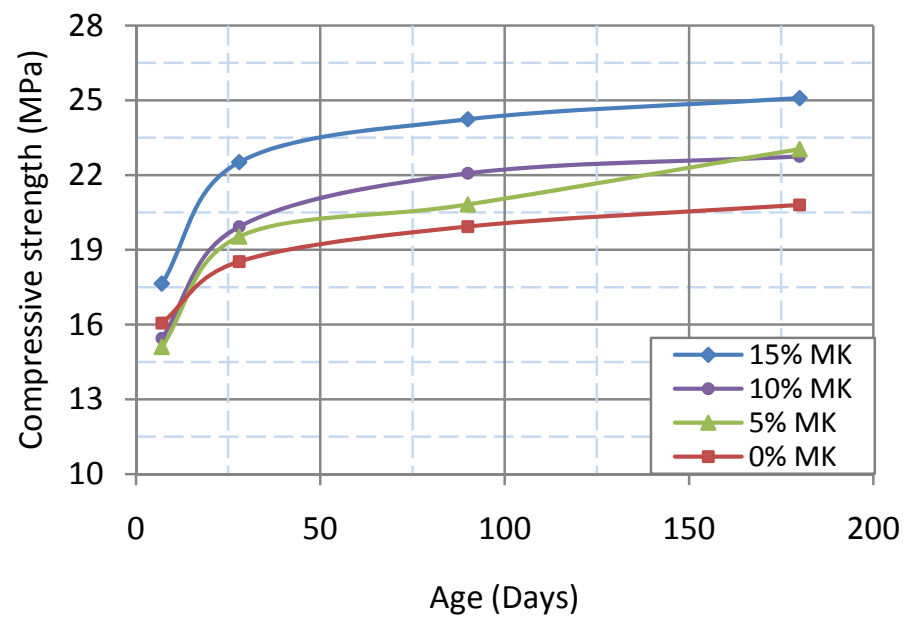

Figure 6: Compressive strength-age relationship for various metakaolin ratios.

The expression suggested by BS EN 1992-1-1 [15] to estimate the compressive strength at time (t) has been checked using SPSS statistic software with a nonlinear regression scheme to investigate its consistency with the results of high metakaolin lightweight aggregate concrete, the estimated expression is:

$$
f_{c m}(t)=\beta_{c c}(t) f_{c m}
$$


where

$$
\beta_{c c}(t)=\exp \left\{s\left[1-\left(\frac{28}{t}\right)^{1 / 2}\right]\right\}
$$

(s) depends on the type of cement and curing temperature, it is in range of (0.20.38 ). However, (s)value of $15 \%$ metakaolin concrete mix was 0.29 with $\mathrm{R}$ squared of $(\approx 80 \%)$.

The pozzolanic reactivity of metakaolin material which is described in BS EN 196-5 [16] was measured according to values of compressive strength as in [17]. The specific strength ratio $R$ which is an indicator of contribution of mineral admixture to strength is defined as

$$
R=f_{c} / p
$$

where $f_{c}$ is the compressive strength and $p$ is the hydraulic cement or mineral admixture percentage. By eliminating the reduction effect of the glass aggregate on the values of compressive strength, the contribution of the pozzolanic effect of metakaolin $R_{p}$ to concrete strength is given by Eq. (5).

$$
R_{p}=R_{M}-R_{C}
$$

where $R_{M}$ the contribution of unit hydraulic cement when metakaolin is used and $R_{C}$ the contribution of unit hydraulic cement to the concrete strength without using metakaolin material.

The index specific strength $K$ is the ratio of $R_{M}$ to $R_{C}$. The contribution of pozzolanic effect $P$ to concrete strength can be expressed as:

$$
P=\left(R_{P} / R_{M}\right) \times 100
$$

The values of $R, R_{p}, K$ and $P$ for controlled and modified concrete mixes at ages of 7, 28, 90 and 180 days were calculated and presented in Table 1.

The benefit of metakaolin on the strength of concrete can be clearly seen. This benefit increases with an increase of metakaolin content, where up to $30 \%$ of the concrete strength resulted from the pozzolanic action of metakaolin material. For all modified concrete mixes, the improvement of compressive strength continues for long term duration (180 days), this is in agreement with the results of $[4,17]$. On the other hand, at earlier ages (7 days) the compressive strength decreased for concrete mixes containing 5\% and $10 \%$ metakaolin. This may be due to the negative effect of glass aggregate on the strength which reduces the amount of hydration products at this time. 
Computational Methods and Experimental Measurements XV 93

\begin{tabular}{|c|c|c|c|c|c|c|}
\hline \multirow{4}{*}{$\begin{array}{l}\sum \\
\text { in } \\
\text { in } \\
+ \\
0 \\
\text { in } \\
\text { in }\end{array}$} & 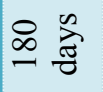 & $\begin{array}{l}8 \\
i d \\
\ddot{i}\end{array}$ & กิ & $\begin{array}{l}1 \\
0 \\
0 \\
0\end{array}$ & ণ্ণ & ஸे \\
\hline & ๙ ๙ స્త్ర & $\stackrel{\stackrel{ \pm}{+}}{\stackrel{d}{ }}$ & 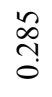 & $\begin{array}{l}n \\
\stackrel{\infty}{0} \\
0\end{array}$ & $\stackrel{n}{\stackrel{n}{\leftrightarrows}}$ & oे \\
\hline & 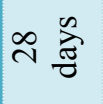 & $\begin{array}{l}\tilde{n} \\
\text { ป }\end{array}$ & 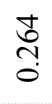 & $\stackrel{0}{0}$ & $\stackrel{n}{ָ}$ & ?. \\
\hline & 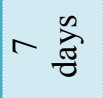 & $\stackrel{\Xi}{\stackrel{J}{I}}$ & ஸ़ & $\begin{array}{l}0 \\
0 \\
0\end{array}$ & $\stackrel{\infty}{\circ}$ & $\begin{array}{l}\bar{b} \\
\text { ì }\end{array}$ \\
\hline \multirow{4}{*}{$\begin{array}{l}\sum^{y} \\
\text { oे } \\
0 \\
+ \\
0 \\
\text { ò } \\
\text { in }\end{array}$} & $\stackrel{\infty}{\infty}$ & $\frac{n}{i}$ & กิ & $\stackrel{J}{\stackrel{J}{0}}$ & $\hat{o}$ & 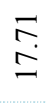 \\
\hline & ๙ స స్త్ర & $\begin{array}{l}\hat{a} \\
\text { ì }\end{array}$ & $\stackrel{n}{\stackrel{n}{2}}$ & $\stackrel{n}{0}$ & $\stackrel{5}{\circ}$ & $\begin{array}{l}\stackrel{P}{0} \\
\dot{\infty}\end{array}$ \\
\hline & $\stackrel{\infty}{\text { 入 }}$ & $\stackrel{a}{a}$ & $\underset{\widetilde{\Xi}}{\tilde{\sigma}}$ & 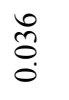 & ڤn & กֶ? \\
\hline & $-\overbrace{\bar{\delta}}^{\infty}$ & $\begin{array}{l}\stackrel{n}{f} \\
\stackrel{n}{\natural}\end{array}$ & $\frac{E}{0}$ & $\ddot{\square}$ & 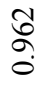 & †े \\
\hline \multirow{4}{*}{$\begin{array}{l}\sum^{v} \\
\text { o } \\
\text { in } \\
0 \\
\text { in } \\
\text { in }\end{array}$} & $\stackrel{\infty}{\infty}$ & $\begin{array}{l}\dot{J} \\
\stackrel{\sim}{ }\end{array}$ & $\stackrel{\stackrel{I}{̃}}{0}$ & 苞 & $\stackrel{5}{\circ}$ & $\begin{array}{l}\stackrel{\vartheta}{ \pm} \\
\pm\end{array}$ \\
\hline & ๙ & $\begin{array}{l}\text { D } \\
\stackrel{\sim}{\dot{\nu}}\end{array}$ & $\frac{a}{\tilde{0}}$ & $\stackrel{a}{\circ}$ & $\underset{+}{\stackrel{J}{0}}$ & $\stackrel{+}{0}$ \\
\hline & $\stackrel{\infty}{\sim} \underset{\text { స }}{\stackrel{\infty}{\sigma}}$ & $\tilde{n}$ & ڤ̊̀ & ণิ & $\hat{\tilde{c}}$ & $\begin{array}{l}\circ \\
\infty \\
a\end{array}$ \\
\hline & $-\sum_{\text {స్త }}^{\infty}$ & $\ddot{n}$ & $\stackrel{\infty}{\stackrel{n}{n}}$ & , & 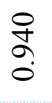 & ô. \\
\hline \multirow{4}{*}{ 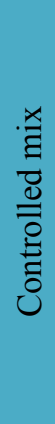 } & $\stackrel{\infty}{\infty}$ & $\stackrel{\infty}{\stackrel{\sim}{~}}$ & 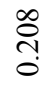 & $\begin{array}{l}8 \\
8 \\
0\end{array}$ & $\stackrel{8}{8}$ & $\begin{array}{l}8 \\
8 \\
0\end{array}$ \\
\hline & ๙ & $\stackrel{\check{\alpha}}{\sigma}$ & $\frac{2}{0}$ & $\begin{array}{l}8 \\
8 \\
0\end{array}$ & $\stackrel{8}{8}$ & $\begin{array}{l}8 \\
8 \\
0\end{array}$ \\
\hline & $\stackrel{\infty}{\text { స }}$ & $\begin{array}{l}n \\
\tilde{\infty} \\
\infty\end{array}$ & $\frac{n}{\infty}$ & $\begin{array}{l}8 \\
8 \\
0\end{array}$ & $\stackrel{8}{\circ}$ & $\begin{array}{l}8 \\
8 \\
0\end{array}$ \\
\hline & 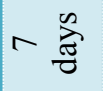 & $\begin{array}{l}8 \\
0 \\
0\end{array}$ & $\frac{8}{8}$ & $\begin{array}{l}8 \\
8 \\
0\end{array}$ & \& & $\begin{array}{l}8 \\
8 \\
0\end{array}$ \\
\hline & $\begin{array}{l}\text { ure.ted } \\
\text { OZZO d }^{2}\end{array}$ & & $\approx$ & $c^{2}$ & 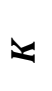 & $\overbrace{}^{\circ}$ \\
\hline
\end{tabular}




\subsection{Splitting tensile strength}

Improvements in splitting tensile strength were observed for modified concrete mixes relative to controlled mix as shown in Figure 7. These may be related to an increase in compressive strength of theses mixes resulting from the pozzolanic action of metakaolin material. The splitting tensile strength increases whenever metakaolin content increased. However, a slight decrease was recorded for the mix containing $10 \%$ metakaolin at age of 180 days relative to concrete mix of $5 \%$ metakaolin. This behaviour could be due to the surface effect of specimens. Percentage increases in splitting tensile strength of concrete mixes containing 5\%, 10\% and 15\% metakaolin material at age of 120 day compared with the controlled concrete mix were $11 \%, 12.5 \%$ and $26 \%$ respectively.

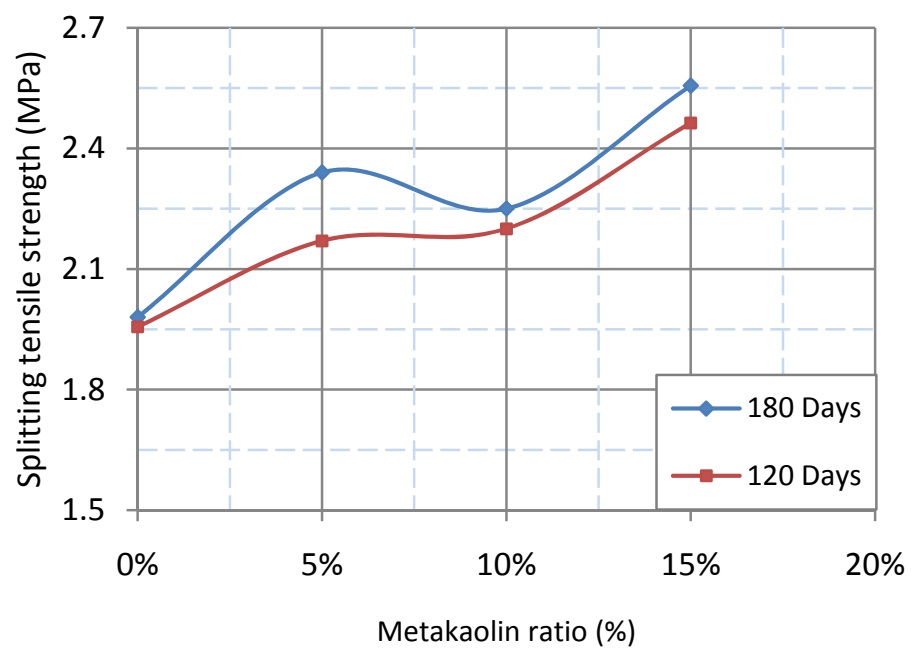

Figure 7: Effect of metakaolin ratio on the splitting tensile strength of lightweight concretes.

\section{Conclusions}

The experimental measurements of high metakaolin lightweight aggregate concrete were reported, discussed and then compared with the mechanical behaviour of lower metakaolin contents. The main results can be summarized as follow:

- The high metakaolin lightweight aggregate mix exhibited inferior workability due to its role in acceleration the hydration of cement, while an adequate workability was recorded to the lower metakaolin contents.

- A slightly decreasing in density values of modified concrete mixes compared with the controlled mix and the higher reduction was at $10 \%$ metakaolin content for all test ages. 
- A vast improvements in value of compressive strength were achieved when metakaolin material is used as a partially substitute to ordinary Portland cement.

- The pozzolanic activity of the metakaolin material increases with an increase of its content, and it reached up to $30 \%$ from the contribution aspect of compressive strength.

- The pozzolanic action of metakaolin material continues improved the long term behaviour of lightweight aggregate concrete.

- Consistent positive improvements in tensile strength to that in compression feature were also recorded at short and long term behaviours.

\section{Acknowledgements}

The authors would like to express their gratitude to the Plasmor Concrete Product Company, staff of the Civil Engineering Laboratory of the University of Manchester and the Ministry of Higher Education and Scientific Research in Iraq.

\section{References}

[1] Miao, L., Incorporating ground glass in self-compacting concrete, Construction and Building Material, 25, 919-925, 2011.

[2] Eva, V., et al., High performance concrete with Czech metakaolin: Experimental analysis of strength, toughness and durability characteristics, Construction and Building Material, 24, 1404-1411, 2010.

[3] Parande, A., et al., Metakaolin: a versatile material to enhance the durability of concrete - an overview, Institute of Civil Engineering, doi: 10.1680/stco, 2009.

[4] Wild, S., et al., A relative strength, pozzolanic activity and cement hydration in superplasticised metakaolin concrete, Cement and Construction research, 26, No.10, 1537-1544, 1996.

[5] Kayali, O., Fly ash lightweight aggregates in high performance concrete, Construction and Building Materials, 22 (12): 2393-2399, 2008.

[6] BS EN 12390-1, Making and curing specimens for strength test, British Standards: 1-12, 2009.

[7] BS EN 206-1, Concrete: Specification, performance, production and Conformity, British Standards: 1-74, 2000.

[8] BS EN 12390-7, Testing hardened concrete, Part 7: Density of hardened concrete, British Standards: 1-14, 2009.

[9] BS EN12390-3, Testing hardened concrete, Part 3: Compressive strength of test specimens' British Standards: 1-22, 2009.

[10] BS EN 12390-6, Testing hardened concrete, Part 6: Splitting tensile strength of test specimens, British Standards: 1-14, 2009.

[11] BS ISO 1920-10, Testing of concrete, Part 10: Determination of static modulus of elasticity, British Standards: 1-12, 2009. 
[12] Roy, D., et al., Effect of silica fume, metakaolin, and low calcium fly ash on chemical resistance of concrete, Cement and Concrete Researches, 31, 1809-1813, 2001.

[13] Batis G, P., The effect of metakaolin on the corrosion behaviour of cement mortar, Cement and Concrete Composition, 27, 125-130, 2005.

[14] Kim, H., et al., Strength properties and durability aspects of high strength concrete using Korean metakaolin, Construction and Building Materials, 21: 1229-1237, 2007.

[15] BS EN 1992-1-1, Eurocode 2: Design of concrete structures: Part 1-1: General rules and rules for buildings, British Standards: 1-230, 2004.

[16] BS EN 196-5, Method of testing cement: Part 5: Pozzolanicity test for pozzolanic cement, British Standards: 1-16, 2005.

[17] Kiruthia, J., et al., Self-compensating autogenous shrinkage in PC-MK-fly ash pastes, Advance in Cement Research, 12, No.1, 35-43, 2001.

[18] Paulo, C., et al., Effect of Portuguese metakaolin on hydraulic lime concrete using different curing conditions, Construction and Building Materials, 24: 71-78, 2010. 